\title{
Review of Ibrahim SAWEROS,
}

\section{ANOTHER ATHANASIUS: FOUR SAHIDIC HOMILIES ATTRIBUTED TO ST. ATHANASIUS OF ALEXANDRIA}

\author{
Samuel MOAWAD*
}

\begin{abstract}
Ibrahim Saweros. Another Athanasius: Four Sahidic Homilies attributed to St. Athanasius of Alexandria. Introduction, Editions, Translations. Ph.D dissertation, Leiden University, Netherlands, 2016 [XIII + 321 pages].
\end{abstract}

The book deals with four unpublished homilies written in Sahidic Coptic and falsely attributed to Athanasius, the famous Archbishop of Alexandria (328-373). These pseudepigraphic texts belong to the Hâamūlī find discovered near al-Fayyūm in 1910 and are now preserved in the Morgan Library in New York (USA). The first homily is On Michael and Gabriel, the Archangels from codex M602 (ff. 89r-98r). The second text occurs in the same codex (ff. 98v-110v) and has the title of "On Murder and Greed and on Michael", the Archangel. The third text, On Luke 11: 5-9, is found in codex M577 (ff. 37v-49v). The last homily is On Pentecost which occupies folios $118 \mathrm{v}-140 \mathrm{v}$ of codex M595.

The core of the dissertation is the edition of the above mentioned homilies with English translation (pp. 107-292) followed by a bibliography (pp. 293-310) and a summary in English, Dutch and Arabic (pp. 311-320). In his introduction to the edition (pp. 1-105) the author gives a summary of the Hāmūlī find, its history, and its content in general (pp. 1-5). Then the author devotes the next pages (5-21) to the individual homilies he edited and presents the codicological as well as the linguistic features of the codices in which they are included. In the chapter entitled "Literary Analysis" (23-57) the author summarizes every homily and analyzes its components to find out the intention of the orginal author and which literary methods he used to reach his aim. At the end of every homily Saweros offers a table of contents of the homily in discussion and indicates the place of every part of it in his edition as well as in the manuscript. The question concerning authorship, date and place of the homilies is explored in a separate chapter (pp. 59-71). Since every homily has its own style and Sitzim Leben Saweros decided to study them separately.

\footnotetext{
${ }^{*}$ WesfälischeWilhelms-UniversitätMünster (Germany)
} 
It is clear to every scholar who is familiar with the authentic writings of Athanasius of Alexandria that the four homilies in discussion are inauthentic. However, these pseudepigraphic homilies "do not offer reliable clues to the identity of their authors", as Saweros himself states (p. 61). For the first homily, Saweros suggests an Alexandrian background and thus he does not exclude Greek as an original language. He puts its date between the sixth and the eighth century. While the real author remains anonymous, he could be a monk. As for the second homily, it or a part of it can be dated back to the fifth century or later. According to the strong Pachomian interest in this homily, the place of its formation or its redaction should be a monastic milieu. The third homily, according to Saweros, consists of several stories of different origins which lead to assume that we have to work here with more than one author. The last homily is of a different style since storytelling is absent and it possesses a strong sense of unity. In the homily itself, the name of Athanasius is absent. It appears only in the title which has been added later. The author could be a bishop who wrote in Greek.

With this book Saweros makes these four Sahidic texts, through his English translation, accessible to a wider public including non-specialists in Coptic studies. His research gives a good example how to use pseudepigraphic texts to study the development of the Coptic identity by showing which image Athanasius had in the Coptic collective memory around the Arab conquest in the seventh century, namely the image of a pastor rather than of a theologian. Moreover, his study of the relationship between these homilies and some older writings, in particular apocryphal texts, indicates the surviving and re-using of this literature in the $9^{\text {th }} / 10^{\text {th }}$ Hâmūlì corpus.

However, there are some points which are missing in this research but by no way have influence on its scientific quality. For example, the dissertation lacks a general preface or foreword which should introduce the theme to the readers, in particular nonspecialists, and to pave their ways to follow the research and its aim.

Furthermore, the methodology used in the edition of the Coptic text varies between a critical edition and a diplomatic one. The author decided to ignore all superlineation "because the superlineation of the manuscripts is non-standard and follows no obvious rule" (p. 103). It is however known that most, if not all, of the Coptic manuscripts do not contain an entirely systematic superlineation. It would be better in this case to mention the superlineation as it is in the manuscripts or to standardize it, not by anyway to ignore it totally.

A bibliographical note should be added here. In the footnotes as well as in the reference list, the author used to mention Arabic references in English translation which makes it impossible for the reader to recognize these references (see note 5 on page 5 and note 44 on page 44). Such references written in non-European languages

- 78 - Another Athanasius: Four Sahidic Homilies attributed to St. Athanasius 
should be written in the established transliteration system and if necessary accompanied with a translation in addition.

The present author congratulates Dr. Ibrahim Saweros for this achievement and urges him to continue his research on the Hâmūlī manuscripts and other Coptic texts attributed to Athanasius and to make use of his experience with this genre of Coptic literature. 